\title{
THE IMPACT OF CHANGES IN SOUTH KOREAN ECONOMIC POLICY ON POST- SECONDARY EDUCATION IN THE EARLY 1970s
}

\author{
Julia Lim Pay Loo
}

\section{Changes in Economic Policy}

The change in economic policy was one of the major changes in South Korea's national policy in the late 1960s. There began a focus on providing investment and incentives to companies to concentrate on heavy industries. This was an enforced change due to an economic crisis in 1969 that saw the government reorganizing the largely insolvent business environment.

In the early 1960s, the South Korean government promoted a number of policies for the country's modernization. By the end of the decade, Korean economy showed a number of encouraging results: 1) The world's highest growth rate of $15.5 \%$; 2) neartarget exports of $\$ 700$ million; 3) The mining proportion of industrial output up to $26.1 \%$; 4) A rapid expansion of Social Overhead Capital; and 5) GNP per capita at $\$ 195 .{ }^{1}$

However, throughout 1969, a number of concerns became apparent: inflation; currency value fluctuations; an imbalance between agricultural and industrial development; the negative impacts on capital of international payments and the pressure of external debt; the growing number of insolvent companies and deterioration of entrepreneurial ethics; the radical rise in the level of wages; a weakening of international competitiveness; as well as a rising trend of excessive consumption. These were problems closely identified with economic growth. Thus, after the rapid growth and the accompanying inflation due to the limitations of a voluntary savings investment that led to a funding shortage, foreign investment was required to make up the shortfall in domestic sources. This resulted in a balance of payments crisis and led to the imbalance between industrial and agricultural development; the growth being promoted in the short term led to the rapid decline of the old system. The trend of consumption nationally surged dramatically, fuelled by high employment levels that saw annual wages rise by more than $25 \%$. Meanwhile, large numbers of businesses became insolvent due, in large part, to the lack of knowledge and experience during the early stages of industrialization. ${ }^{2}$ In the wake of the crisis of 1969, President Park Chung-Hee ordered the reorganization of the business environment and set sustainable growth as well as price stability as key elements of South Korea's economic policy. He

\footnotetext{
<? Dong-A Ilbo mail, “Dong-A Yearbook 1970”, Dong-A Ilbo, pp 512.

2 Ibid 512.
} 
also placed emphasis on the Saemaul Undong (New Village Movement), development of heavy chemical industry and increasing exports for aggressive rural modernization. ${ }^{3}$

A major pre-requisite of implementation of these policies was the cleanup and reorganization of the South Korean business environment toward a future based on heavy industry. As a fundamental requirement for these excessive growth-oriented policies, the reorganization of the business environment was the first step carried out in early 1969. In the second half of the same year, government-dictated measures were taken to restrict damaging inflation. Such a policy put pressure on company finances, inhibiting the production activities of the enterprises, and led to a spike in corporate insolvencies and then to a slump in business confidence and cash flow issues with the banks that would impair rapid growth. As a result of these issues, the government realized that economic reorganization was inevitable and sought active solutions. However, the seriousness of the situation was felt most by banks that shouldered the insolvent companies. ${ }^{4}$ These were a direct result of policies that promoted the inflow of foreign capital through large-scale loans and the inefficient management of soon to be insolvent indebted companies.

Eventually, the government acted to reorganize the business environment. From the end of 1968, the delinquent companies, together with the indebted businesses were surveyed. In early May 1969, seven corporate maintenance plans were established in order to strengthen the economic fundamentals. 30 companies under the Cheon Woo umbrella were ordered to change their management structure, provoking strong opposition from the business world. These were the first targets of the reorganization plan, and included existing (and soon to be formed) companies: Dae Han Plastic Co. Ltd; KongYoung Chemical Co. Ltd; Incheon Steel Co. Ltd; Korea Electrotechnology Metallurgy; Samhwa Steel;, Daesung Wood; Cheon Woo; Shin Jin Toys; Chonson Leather; Samick Shipping; Korea Livestock; Asia Motors; Korea Iron\& Steel; Han Kook Steel \& Mill; SamyangSusan; Samyang Tourism; Samyang Development Co. Ltd; Samyang Sailing; Cheonyang Fisheries; Cheonyang Firm,; DaeYoung Fisheries; Samhae Fisheries; Yohan Spinning and weaving company; Shipping Corporation; Donglim Industry; Donyang Chemical Co. Ltd; ShinYeo development; Shin Yeo Fisheries; and Shin Yeo frozen. These companies had a total capitalization of 77.39 billion won and debt of 72.7 billion won. ${ }^{5}$

According to a report by the Treasury department of the Democratic Republican Party (DRP) at that point in time, the insolvencies resulted from some major overseas capital providers having management that did not meet international standards, underdeveloped manufacturing processes, a heavy burden of interest, and had failed to secure adequate markets for the manufactured goods. Consequently, the government brought in a foreign investment promotion policy, the aims of which were: to guarantee the huge debt faced by insolvent companies or bail out the bank loans; to force failing businesses to reorganize their asset and management structures; and to restructure indebted companies under a new government-sponsored body. These were carried out in spite of savage criticisms of 'property infringement' and violation of the concept of 'free economy'.

3 Ibid 512.

4 Ohwoncheol, 1995, “经济 秘史 Korean economic construction: Engineering Approach 2", Kia Economic Research Institute, pp 286.

5 Dong-A Ilbo mail, “Dong-A Yearbook 1970”, Dong-A Ilbo. pp 515 
The reorganization of the business environment was managed from the Blue House, the office of the president. A professional review of the issues was done by practitioners from the Economic Planning Board, the Ministry of Finance, the Ministry of Commerce, the Bank of Korea, the Development Bank and the Industrial Bank of Korea (IBK) who were dispatched to the Blue House. ${ }^{6}$ Thus the government began to deviate from a 'free economy' to further the maintenance of the indebted business environment. The citizens, under the justification of economic development made excessive sacrifices in furtherance of private enterprise. As these enterprises could not cope with the foreign capital problems, the burden eventually shifted to the national economy. By restricting private enterprise and focusing on a 'National Economy' it was expected that there would be an increase in employment, production and income nationwide. In order to achieve such expectations, it was predicted that direct taxation on the population would foster the private sector and give financial incentives to business in general. Under the justification of economic development, the solution to the problem of insolvent companies was selling them to the general public. The people were told by the government that it was their responsibility to reduce the nation's debt as well as restore business trust. In other words, it was their national duty. ${ }^{7}$ The economic crisis of 1969 was a direct consequence of rapid economic growth that exposed inadequacies in the abilities of capital providers and management structures to keep pace. Major restructuring was therefore needed so that the nation's economy could continue to grow. Soon thereafter, in 1971, the second Five Year Plan was to end and the third one (1972-1976) was due to begin. The aims of the third Five Year Economic Plan can be summarized as follows: 1) growth, safety and harmonious balance between the economic sectors; 2) creation of a self-sustaining economic structure; and 3) Balance of regional development. To these three basic sentiments were later added eight specific goals: 1) To increase the production of food and agricultural income and improve agricultural efficiency through reorganization and mechanization with selfsufficiency in staple foods a key target; 2) To improve health and cultural facilities in rural areas and expand the telephone and road networks into the countryside; 3) To improve international balance of trade by targeting $\$ 3.5$ billion in exports per year; 4 ) To develop heavy industry, 5) To achieve maximum employment by rapidly improving technology and expanding educational facilities to better train the workforce ; 6) To balance development of infrastructure facilities such as power, transportation, health care, port facilities, and communications. 7) To efficiently develop land resources including the four major river basins and export industrial zones; 8) To improve working, welfare and living environments for the people by expanding housing and sanitation facilities and social security. The overall target of the Third Five-Year Plan was to slightly reduce the average annual growth rate from $11.6 \%$ (achieved under the Second Five-Year Plan) to $8.6 \%$ in order to achieve a balance between sectors, a cooling down of the overheated economy, harmonizing growth and stability, and to improve low-productivity sectors including the rural sector and small retail businesses.

The actual changes are shown below in Table 1, 2, 3 and 4. Between 1970 and 1976, the proportion of GNP for the Agriculture and Fisheries sector dropped from $28.4 \%$ to $22.4 \%$. Social Overhead Capital and other sectors showed a relatively small decline from $49.9 \%$ to $49.7 \%$, while the proportion of mining showed a significant increase,

6 Chosun Ilbo, 14 May 1969.

7 Chosun Ilbo, 19 July 1969. 
from $21.7 \%$ to $27.9 \%$. There was particular emphasis in the Third Five Year Plan on the heavy and chemical industries of the manufacturing sector, which increased from $35.9 \%$ in 1970 to $40.5 \%$ in 1976 . The proportion of light industry decreased from $64.1 \%$ in 1970 to $59.5 \%$ in 1976, reflecting advancement and upgrading of the industrial sector.

Table 1: Industry Growth and Structure ${ }^{8}$

\begin{tabular}{|l|c|c|c|c|c|c|}
\hline \multirow{2}{*}{$\begin{array}{l}\text { Year } \\
\text { Sector }\end{array}$} & \multicolumn{2}{|c|}{1970} & \multicolumn{2}{c|}{1976} & \multicolumn{2}{c|}{$\begin{array}{c}\text { Average Annual Growth } \\
\text { rate }\end{array}$} \\
\cline { 2 - 7 } & $\begin{array}{c}\text { Added } \\
\text { Value }\end{array}$ & Percentage & $\begin{array}{c}\text { Added } \\
\text { Value }\end{array}$ & Percentage & $72 \sim 76$ & $67 \sim 71$ \\
\hline GNP & $2,562.0$ & 100.0 & $4,257.1$ & 100.0 & 8.6 & 11.6 \\
\hline Agriculture and Fisheries & 727.8 & 28.4 & 955.2 & 22.4 & 4.5 & 3.0 \\
\hline Mining and Manufacturing & 555.3 & 21.7 & $1,186.6$ & 27.9 & 13.0 & 20.6 \\
\hline $\begin{array}{l}\text { Social Overhead Capital and } \\
\text { Other Sectors }\end{array}$ & $1,278.9$ & 49.9 & $2,115.3$ & 49.7 & 8.5 & 13.2 \\
\hline (Social Overhead Capital) & $(340.8)$ & $(13.3)$ & $(686.2)$ & $(16.1)$ & $(12.3)$ & $(19.8)$ \\
\hline
\end{tabular}

Prices in 1970. Unit: 1 billion Won

Table 2: Industrial Structure ${ }^{9}$

\begin{tabular}{|l|c|c|c|c|c|}
\hline \multirow{2}{*}{$\begin{array}{l}\text { Year } \\
\text { Sector }\end{array}$} & \multicolumn{2}{|c|}{1970} & \multicolumn{2}{c|}{1976} & \multirow{2}{*}{ Growth (\%) } \\
\cline { 2 - 5 } & Amount & Percentage & Amount & Percentage & \\
\hline Manufacturing & 1,668 & 100.0 & 3,891 & 100.0 & 133.3 \\
\hline Heavy Industry & 598 & 35.9 & 1,577 & 40.5 & 163.7 \\
\hline Light Industry & 1,070 & 64.1 & 2,314 & 59.5 & 116.3 \\
\hline
\end{tabular}

Value based at industrial output of 1970 (billions of Won)

Table 3: Investment Allocation by Industry ${ }^{10}$

\begin{tabular}{|l|c|c|c|c|}
\hline \multirow{2}{*}{$\begin{array}{l}\text { Year } \\
\text { Sector }\end{array}$} & \multicolumn{3}{|c|}{ Capital Formation } & $\begin{array}{c}\text { Investment } \\
\text { Expenditure }\end{array}$ \\
\cline { 2 - 5 } & $1972 \sim 76$ & $1967 \sim 71$ & $\begin{array}{c}\text { Increase Rate } \\
(\%)\end{array}$ & $1972 \sim 1976 ?$ \\
\hline The Total Investment & $4,524.5$ & $2,999.6$ & 50.8 & $4,777.7$ \\
\hline Agriculture and Fisheries & 536.1 & 189.0 & 183.6 & 648.5 \\
\hline Mining and Manufacturing & $1,301.9$ & 883.0 & 47.4 & $1,312.7$ \\
\hline Mining & 66.6 & 28.9 & 130.4 & 66.6 \\
\hline Manufacturing & $1,235.3$ & 854.1 & 44.6 & $1,246.1$ \\
\hline $\begin{array}{l}\text { Social Overhead Capital and } \\
\text { Other Sectors }\end{array}$ & $2,686.5$ & $1,927.6$ & 39.4 & $2,816.5$ \\
\hline
\end{tabular}

Prices in 1970. Unit: 1 billion Won

8 Dong-A Ilbo mail, “Dong-A Yearbook”, Dong-A Ilbo, 1972 pp 362.

9 Dong-A Ilbo mail, "Dong-A Yearbook", Dong-A Ilbo, 1972, pp 363.

10 Dong-A Ilbo mail, "Dong-A Yearbook", Dong-A Ilbo, 1972, pp 363. 
This became the launching pad for Korea's economic development throughout the 1970s which also included developments in the defense and heavy chemical industries, reforms in the technical education system, the fostering of research institutions, a review of energy policy and expansion of engineering projects in the Middle East as well as domestic investment in the capital plant industry. ${ }^{11}$ In January 1973, President Park Chung Hee effectively realigned the South Korean economy in order to support the defense industry. The government's priority was exports, developing heavy industry so that these targets could be achieved. In the heavy industries, the president focused on the important sectors of Steel, Chemicals, Non-Ferrous Metals, Machinery, Shipbuilding and Electronics. ${ }^{12}$ Instead of US-educated government officers who understood economic theories, the President selected technocrats from an engineering background, including Oh Won Chol (오원철) and Kim Chung-yum (김정렴). They formed and promoted heavy industry through their so called "Triarchy Policies". ${ }^{13}$

Table 4: Ministry of Commerce and Industry - Annual Industrial Export Plan ${ }^{14}$

\begin{tabular}{|c|c|c|c|c|c|c|c|c|c|c|}
\hline Sectors and Year & 72 & 73 & 74 & 75 & 76 & 77 & 78 & 79 & 80 & 1980 / 1972 \\
\hline \multirow[t]{2}{*}{$\begin{array}{l}\text { Manufactured } \\
\text { Goods }\end{array}$} & 1,584 & 2,080 & 2,680 & 3,370 & 4,160 & 5,100 & 6,230 & 7,620 & 9,300 & 5.9 \\
\hline & $(100 \%)$ & $(100)$ & (100) & (100) & $(100)$ & (100) & $(100)$ & (100) & $(100)$ & \\
\hline \multirow[t]{2}{*}{ 1. Heavy Industry } & 427 & 650 & 970 & 1,330 & 1,830 & 2,460 & 3,270 & 4,300 & 5,630 & 13.2 \\
\hline & $(27.0 \%)$ & (31.3) & $(36.2)$ & (39.5) & $(44.0)$ & $(48.2)$ & $(52.5)$ & $(56.4)$ & $(60.5)$ & \\
\hline A)Chemical & 79 & 85 & 110 & 160 & 208 & 251 & 303 & 365 & 445 & 5.6 \\
\hline B)Metal Products & 120 & 150 & 190 & 250 & 333 & 435 & 570 & 725 & 930 & 7.8 \\
\hline $\begin{array}{l}\text { C)General } \\
\text { Machinery }\end{array}$ & 16 & 22 & 34 & 40 & 59 & 124 & 202 & 305 & 450 & 28.1 \\
\hline $\begin{array}{l}\text { D)Electrical } \\
\text { Machinery }\end{array}$ & 169 & 323 & 490 & 660 & 830 & 1,100 & 1,450 & 1,900 & 2,400 & 14.2 \\
\hline E) Shipping & 43 & 70 & 150 & 220 & 400 & 550 & 745 & 1,005 & 1,405 & 32.7 \\
\hline \multirow[t]{2}{*}{ 2. Light Industrial } & 1,157 & 1,430 & 1,710 & 2,040 & 2,330 & 2,640 & 2,960 & 3,320 & 3,670 & 3.2 \\
\hline & $(73.0 \%)$ & $(68.7)$ & $(63.8)$ & $(60.5)$ & $(56.00$ & $(51.8)$ & $(47.5)$ & $(43.7)$ & (39.5) & \\
\hline A)Textiles & 722 & 860 & 1,020 & 1,230 & 1,430 & 1,640 & 1,840 & 2,050 & 2,280 & 3.2 \\
\hline B)Others & 435 & 570 & 690 & 810 & 900 & 1,000 & 1,120 & 1,270 & 1,390 & 3.2 \\
\hline
\end{tabular}

Unit: USD Millions

Labour economics from 1969 were hugely impacted by the drive toward heavy industry, the development of the workforce and technological innovation. A new type of workforce was needed because of the demands of the new heavy industry-based economy. The changes in the structure of employment to support the planned heavy industries resulted in new policies for human resource development. As for the changes

11 Oh Woncheol, "Energy Policy and the Middle East expansion”, Kia Economic Research Institute, 1997, pp20.

12 Chosun Ilbo, 25 May 1973.

13 Chosun Ilbo, 29 October 2005.

14 Oh Wonchul, "Korean Economic Construction", $7^{\text {th }}$ Korean edition), Korean Economic Policy Institute, 1999, pp 492. 
in the structure of employment, the Agricultural and Fisheries sector decreased to $51.3 \%$ in 1969, down from 52.5\% in 1968 (see Table 5). The 1.2\% reduction was accounted for by an increase of $0.3 \%$ in the mining sector and $0.9 \%$ in the tertiary sector. However, the number employed in the Agriculture and Fisheries sector was almost the same as those employed in secondary and tertiary industries. Nevertheless, the numbers in the Mining sector required attention because they constituted just one third of Social Overhead Capital. The increase of the organic composition of capital in the mining sector required highly-skilled workers and more technicians. ${ }^{15}$ The tempo of technological innovation accelerated once measures for supply of adequately trained technicians were taken. The ratio of people in vocational training to those in the professions was about 2 to 1.

Table 5: Employment Structure - Supply and Demand for Technical Personnel ${ }^{16}$

\begin{tabular}{|c|c|c|c|c|c|c|c|c|c|c|c|}
\hline & \multicolumn{6}{|c|}{ Employment structure by industry(thousands) } & & \multicolumn{2}{|c|}{ Technicians } & \multicolumn{2}{|c|}{ Engineers } \\
\hline & $\begin{array}{l}\text { Agriculture } \\
\text { and Fishery }\end{array}$ & $\%$ & \begin{tabular}{|c|} 
Mining \\
and \\
Manufacturing
\end{tabular} & $\%$ & Tertiary & $\%$ & & Demand & Supply & Demand & Supply \\
\hline 1967 & 4,924 & 55.2 & 1,138 & 12.8 & 2,852 & 32.0 & $67 \sim 71$ & 57,120 & 32,730 & 164,960 & 223,260 \\
\hline 1968 & 4,863 & 52.5 & 1,295 & 14.0 & 3,103 & 33.5 & 1968 & 10,390 & 5,900 & 33,890 & 38,190 \\
\hline 1969 & 4,798 & 51.3 & 1,335 & 14.3 & 3,214 & 34.4 & 1971 & 13,540 & 7,680 & 31,010 & 49,830 \\
\hline $68 / 67(\%)$ & -2.7 & & +1.2 & & +1.5 & & $\begin{array}{c}71 / 68 \\
(\%)\end{array}$ & 30.3 & 33.2 & -8.5 & 30.4 \\
\hline $69 / 68(\%)$ & -1.2 & & +0.3 & & +0.9 & & & & & & \\
\hline
\end{tabular}

The Korean government fixed the direction of the policy for technology improvement. The first phase was to develop science and technology training and educational structure - by initiating research, promoting development and training and improving the quality of post-secondary education. The second was through industry collaboration. The policy aimed at strengthening human resources to attract foreign technology as well as the development of national technical services, improving productivity and industrial competitiveness internationally in order to eliminate technology gap with the advanced countries. The cost of this imported technology reached \$USD 1,164,000 in 1968. This increase covered 139 technologies, mainly in the electrical, heavy industrial and chemical industries. Capital costs of 2.7 billion won and US\$7,352,000, local and foreign investment respectively, were invested in the development of the Korea Institute of Science and Technology, as well as the Scientific and Technological Information Center for the provision of foreign scientific and technical information. ${ }^{17}$ Thereafter, the government concentrated on the domestic development of fundamental technology and the technical development of private enterprises, thus making the nation self-reliant on home-grown technology. Fundamental design of these plans was the promotion of a highly educated workforce dedicated to bringing Korea to the forefront of developed nations.

15 Businesswomen Association of Korea, 1969, “The Korea Economic Yearbook 1969”, Korea Association of Businesswomen, pp 25.

16 Economic Planning Board, Ministry of Science and Technology, South Korea.

17 Ibid pp 26. 


\section{Changes in educational policy in late 1960s and early 1970s}

In President Park Chung Hee's words, until the late 1960s, Korean education could be best described as "an education lacking in national identity". The president, at the Educators Convention held in Daegu on 24 March 1972, pointed out that

The contribution of education to society is huge, yet we have to rigorously reflect on our stateless education up to now. Now is the time to move away from imitating foreign systems, to accurately recognize reality, to base education on the right patriotic foundations (국가관) derived from the specific view of our nation. ${ }^{18}$

South Korea in the 1960s faced many political and economic difficulties, a period when efforts were made to strengthen nationalism to address the failure of the national movement of reconstruction of Korean society to create a new social structure. At the time, the South Korean government ordered the strengthening of nationalism to eliminate internal and external security threats. Meanwhile, the education policy aimed at focusing on the reorganization of the business environment and the development of the heavy and chemical industries. The government saw the domestic balanced development policy as a very powerful aid for security through instilling a sense of national identity.

\section{Strengthening of Nationalism in National Education}

The introduction of "National Education" in the 1970s was a major turning point in Korean education. It was proposed by the government in response to an external security crisis and to reduce the influence of Communism at home. National Education began in 1972 with a sharpening of post-secondary education in both form and content. At that point in time, the remodeling included strengthening ideological education to foster condemnation of North Korea and the strengthening of the Student National Defense Corps. As we have seen, President Park Chung Hee stated that education should be based on right patriotic foundations (국가관 ) to enhance national identity. The right patriotic foundations included focus on the nation's traditions and the country's claim towards autonomy. The three main goals promoted for the cultivation of national power were self-reliance, self-support and self-defense. ${ }^{19}$

'National Education' was implemented through several measures: 1) establishing a committee for the Strengthening of National History Education; 2) doubling of history periods in the middle school curriculum, 3) compulsory liberal arts course on cultural history; 4) a revised and expanded national history textbook at the elementary level; 5) government designated textbooks of national history for middle and high schools; 6) a National Education Charter emphasizing a Korean view of history to establish a nationalistic view. The charter emphasized National Education through educational policies implemented by schools in the 'front line'. By 11 May 1972, the Strengthening of National History committee was formed with influential scholars of national history as its members. These scholars, very recently affected by the colonial experience, were single-minded in reconstructing a national view of the Korean nation.

18 Council for Education, 1973, “Korea Education Yearbook”, Korea Education Newspaper, pp 28.

19 Ibid. 
The measures undertaken by the committee of Strengthening of National History were, firstly, to reorganize national history textbooks with the right depth of content for each educational level. Next was the strengthening of national history education across the board. From 1973, National History was to be taught as an independent subject for fifth and sixth grade elementary schools, and it was recommended as a compulsory subject in high schools and for the college entrance examination, the latter coming into effect on 27th November 1973. Additionally, in 1972, it was independently introduced as a compulsory subject in the civil service recruitment examination, approved by the cabinet on 30 May 1972 and it was also slipped into the employment examination of state enterprises. Graduate School students majoring in National History were given special scholarships. Korea Student Aid Foundation, established by the Ministry of Education, gave the scholarship to a total of 7 students from the second semester, four of whom were from the Graduate School of Seoul National University, and one each in Korea University, Yonsei University and Sogang University.20 On 29 May National History was added to the judicial examination. Overall, it was introduced as a compulsory subject for the various public official examinations, a second test at level four and above, and a onetime test for the 5 th level and above. ${ }^{21}$

Due to a National Emergency on 8 December 1971, the Ministry of Education announced an improved Security Education system across all levels and disciplines. The measures taken were the enhancement of security education, a better schooling system and policies for the establishment of new and improved educational values in security. In response to the Emergency, the Ministry of Education required all schools to participate in training for Security Education. This meant focusing on anti-Communist education and reorientation for teachers as well as the compilation and dissemination of teaching materials designed to counter communist propaganda. This type of education ran alongside practical drills in civil and air defense. The Ministry of Education required, as part of the moral responsibility, to the Nation, that "all faculty, students ... to be united in the recognition of the magnitude of the national emergency...". ${ }^{22}$ Consequently, these policies resulted in daily life based on an anti-Communist spirit together with a fundamentally national defense posture, education and practical drill training. In addition, following a cabinet meeting on June 25, 1971, compulsory military training courses were introduced from the second semester of University. Eventually this policy abolished the Reserve Officer Training Corps (ROTC). ${ }^{23}$

The Ministry of Education's 1969 Scholarship policy (Table 6) implementation followed specific objectives which can be summarized as follows: the establishment of work ethic, the promotion of "lifestyle" education, justification of the curriculum, Hangul-only in education and the duties required of teachers (师道).

\footnotetext{
20 Chosun Ilbo, 30 December 1972.

21 Chosun Ilbo, 30 May 1972.

22 Chosun Ilbo, 9 December 1971.

23 Chosun Ilbo, 18 August 1970.
} 
Table 6: Scholarships By Year 24

\begin{tabular}{|c|c|c|c|c|c|}
\hline Year & $\begin{array}{l}\text { Anti- } \\
\text { Communist } \\
\text { Education }\end{array}$ & Civics & $\begin{array}{l}\text { National } \\
\text { Identity }\end{array}$ & Teacher Training & Production Training \\
\hline 1962 & $\begin{array}{l}\text { Crushing } \\
\text { of Indirect } \\
\text { Aggression }\end{array}$ & $\begin{array}{l}\text { Human } \\
\text { modification }\end{array}$ & & & Poverty alleviation \\
\hline 1963 & $\begin{array}{l}\text { Crushing } \\
\text { of Indirect } \\
\text { Aggression }\end{array}$ & $\begin{array}{l}\text { Human } \\
\text { modification }\end{array}$ & & & Poverty alleviation \\
\hline 1964 & & & & $\begin{array}{l}\text { Democratic } \\
\text { institutions, } \\
\text { improving teaching } \\
\text { methods }\end{array}$ & $\begin{array}{l}\text { Polished } \\
\text { Production Technology }\end{array}$ \\
\hline 1965 & & $\begin{array}{l}\text { Wholesome } \\
\text { Citizenship }\end{array}$ & & & $\begin{array}{l}\text { Promote economic } \\
\text { growth }\end{array}$ \\
\hline 1966 & & & $\begin{array}{l}\text { Establishment } \\
\text { of a national } \\
\text { identity }\end{array}$ & $\begin{array}{l}\text { Creating a } \\
\text { sound academic } \\
\text { atmosphere }\end{array}$ & $\begin{array}{l}\text { Promoting production } \\
\text { Training }\end{array}$ \\
\hline 1967 & & & $\begin{array}{l}\text { Establishment } \\
\text { of a national } \\
\text { identity }\end{array}$ & $\begin{array}{l}\text { Creating a } \\
\text { sound academic } \\
\text { atmosphere }\end{array}$ & $\begin{array}{l}\text { Promoting production } \\
\text { Training }\end{array}$ \\
\hline 1968 & & & $\begin{array}{l}\text { Establishment } \\
\text { of a national } \\
\text { identity }\end{array}$ & $\begin{array}{l}\text { Creating a } \\
\text { sound academic } \\
\text { atmosphere }\end{array}$ & $\begin{array}{l}\text { Promoting production } \\
\text { Training }\end{array}$ \\
\hline 1969 & & $\begin{array}{l}\text { Establishing } \\
\text { ethics }\end{array}$ & $\begin{array}{l}\text { Promotion of } \\
\text { Hangul Only }\end{array}$ & $\begin{array}{l}\text { Normalization } \\
\text { of the Education } \\
\text { Process }\end{array}$ & $\begin{array}{l}\text { Promotion of Self- } \\
\text { Reliance "산교육" }\end{array}$ \\
\hline
\end{tabular}

The National Education charter, including these policies, meant a new definition of national ethics for integrity, diligence, and the temperance demands of the cultivation of lifestyle attitude. In addition, anti-Communism became a way of life and national pride was fostered through values like cultural heritage protection and reverence for ancestors.25 To further fortify this trend, the Ministry of Education introduced a formal course of National Ethics into every level of education starting from May 20, 1970. ${ }^{26}$ Existing irregular and non-compulsory ethics and anti-communist courses in elementary and middle schools became compulsory moral requirements. For high schools, National Ethics was introduced as a new subject. From fall 1970, all South Korean universities taught National Ethics under the auspices of the University Ethics Committee which designed the syllabus, textbooks and lectures. ${ }^{27}$ An example of the focus of the new syllabus is shown in Table 7.

${ }_{24}$ Education Association, "Korea Education Yearbook", Korea Education Newspaper, 1970, pp 95.

25 Council for Education, 1970, "Korea Education Yearbook", Korea Education Newspaper, pp 95.

26 Chosun Ilbo, 21 May 1970.

27 Bak Jungyu, "Civics education and the curriculum," Korea Ministry of Education, 1977, pp 9. 
Table 7: Civics Syllabus ${ }^{28}$

\begin{tabular}{|c|c|}
\hline I & Basic Civic Values \\
\hline & $\begin{array}{l}\text { 1) humanistic } \\
\text { 2) human social skills } \\
\text { 3) the nature of ethics } \\
\text { 4) Personal and national }\end{array}$ \\
\hline II & History and ethnicity \\
\hline & $\begin{array}{l}\text { 1) Purification of national history } \\
\text { 2) World History and Korea } \\
\text { 3) Challenges of national renaissance } \\
\text { 4) Tradition and Creation }\end{array}$ \\
\hline III & The establishment of democracy \\
\hline & $\begin{array}{l}\text { 1) The development of democracy and philosophy } \\
\text { 2) Democratic institutions } \\
\text { 3) Freedom and Control } \\
\text { 4) Indigenization of democracy }\end{array}$ \\
\hline IV & Challenging communism \\
\hline & $\begin{array}{l}\text { 1) Communist strategies and Tactics } \\
\text { 2) The division of the Communist Bloc } \\
\text { 3) North Korea (1) } \\
\text { 4) North Korea (2) }\end{array}$ \\
\hline V & The Nation's Course \\
\hline & $\begin{array}{l}\text { 1) Direction of World History and national identity } \\
\text { 2) Modernization tasks } \\
\text { 3) A common way } \\
\text { 4) The future of the country }\end{array}$ \\
\hline
\end{tabular}

Under National Education, the Ministry of Education created statutory courses in Korean history, military drills and National Ethics in the liberal arts studies in universities. They also planned changes to general education courses to strengthen the university's liberal arts college model. The College of Liberal Arts Education Research Council came up with a new model that made National Ethics a compulsory General Education course. ${ }^{29}$ The establishment of the National Education system under President Park Chung Hee was known as the Reform (유신 ) because it prepared South Koreans for a path towards nation building.

28 Bak Jungyu, "Civics education and the curriculum," Korea Ministry of Education, 1977, pp 9.

29 Chosun Ilbo, 25 February 1970. 


\section{The Restructuring of Engineering Education}

This section discusses the major impact on education policy as a result of South Korea's shift in the late 60's and early 70's toward an economy based on the heavy industries that was focused on exports, defense, and investments in advanced development projects. To achieve these aims, a highly-skilled and well-educated workforce was required. To this end, changes to the structure of university-level Engineering courses and long-term comprehensive education planning in science became the focus. On 13 February 1969 the Long-term Comprehensive Educational Plan was initiated by a Council of 50 technocrats from various fields of expertise under the chairmanship of the Prime Minister. This panel of experts took a year to produce the new plan which included training development plans for economic, political and social curriculum, and the establishment of processes and tools for the renewal of long-term outlook and general direction. The goals and purpose of The Long-term Comprehensive Educational Plan were as follows:

1. The plan aimed to be the driving force behind the development of the country and to be the major axis in instilling the Spirit of the Nation that was the basis of Korean educational system.

2. The purpose of the plan was to directly

a. modernize teaching and learning education to improve internal efficiency

b. provide social and educational needs of the workforce to meet the demands of external productivity

c. establishing and streamlining the support structure for education and training

d. empowering corporate competency in the realization of the system. ${ }^{30}$

In the 1970s, South Korea was considered a developing country. Hence, these goals were expected to enable South Korea's economy to surpass the level of a developing country. The main aim was to modernizing and become an industrialized society. The establishment of economic development plans saw South Korea develop rapidly in achieving an average annual growth rate of 8-9 percent with a wealthy society in place. Exports significantly increased with the transition to an export oriented industrial structure which then led to rapid growth in national income as well as government revenues. Table 8 shows the Republic of Korea's Gross National Product (GNP) achievements from 1968 to 1986.

Under the 1970s economic development plans, though modernized industrial structure and exports dramatically increased, there was a drastic reduction in the value of primary and secondary industries. However, social capital increased.

In 1972, alongside new policies in other sectors, Park Chung-Hee announced the restructuring of the defense-based industries. New policies had to be put in place to face the reality of a new future. President Park saw the need for South Korea to establish export targets to achieve leading construction, chemical, steel, shipbuilding, machinery and petrochemical industries. In addition, the country also had to produce a balanced education plan for each school level, with an emphasis on science and technology.

30 Council for Education, "Korea Education Yearbook", Korea Education Newspaper, 1970, pp 26. 
Table 8: Forecast of GNP by Year ${ }^{31}$

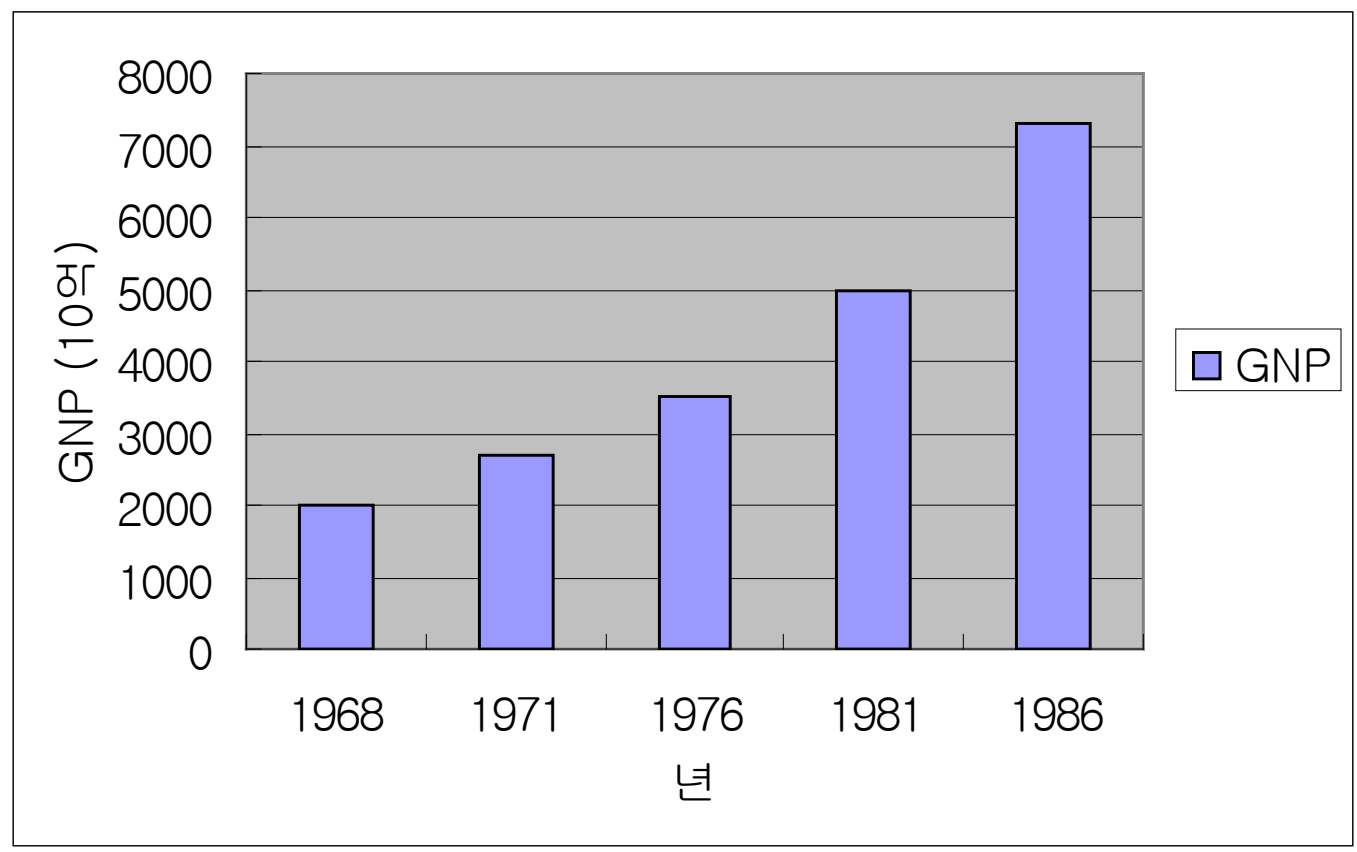

Moreover, human resource development was required to further the country's development. This meant every aspect of business and industrial education had to be modernized to provide a smooth supply of specialist personnel. The government began to impress on the people the need for tertiary education. University, college and graduate school education was strengthened. Graduate education was based upon the production of knowledge in order to innovate, cultivate leadership, achieve enhanced international competitiveness in the knowledge industry, produce high-quality human resources, and most importantly, avoid domestic brain drain. The biggest tertiary development impact was felt in the colleges of natural science and engineering as these departments were expected to provide most of the personnel to drive the planned economic changes. There was a marked increase in the entrance quota from 1967 through 1969 as shown in the table 9 .

In 1967, entrance requirements included science as a compulsory subject to be tested upon. ${ }^{32}$ University entrance began to be based on merit and using the Seoul National University as an example, the following illustrates the changes in curriculum.

31 Education Association, "Korea Education Yearbook", Korea Education Newspaper, 1970, pp 27.

32 Chosun Ilbo, 6 September 1966. 


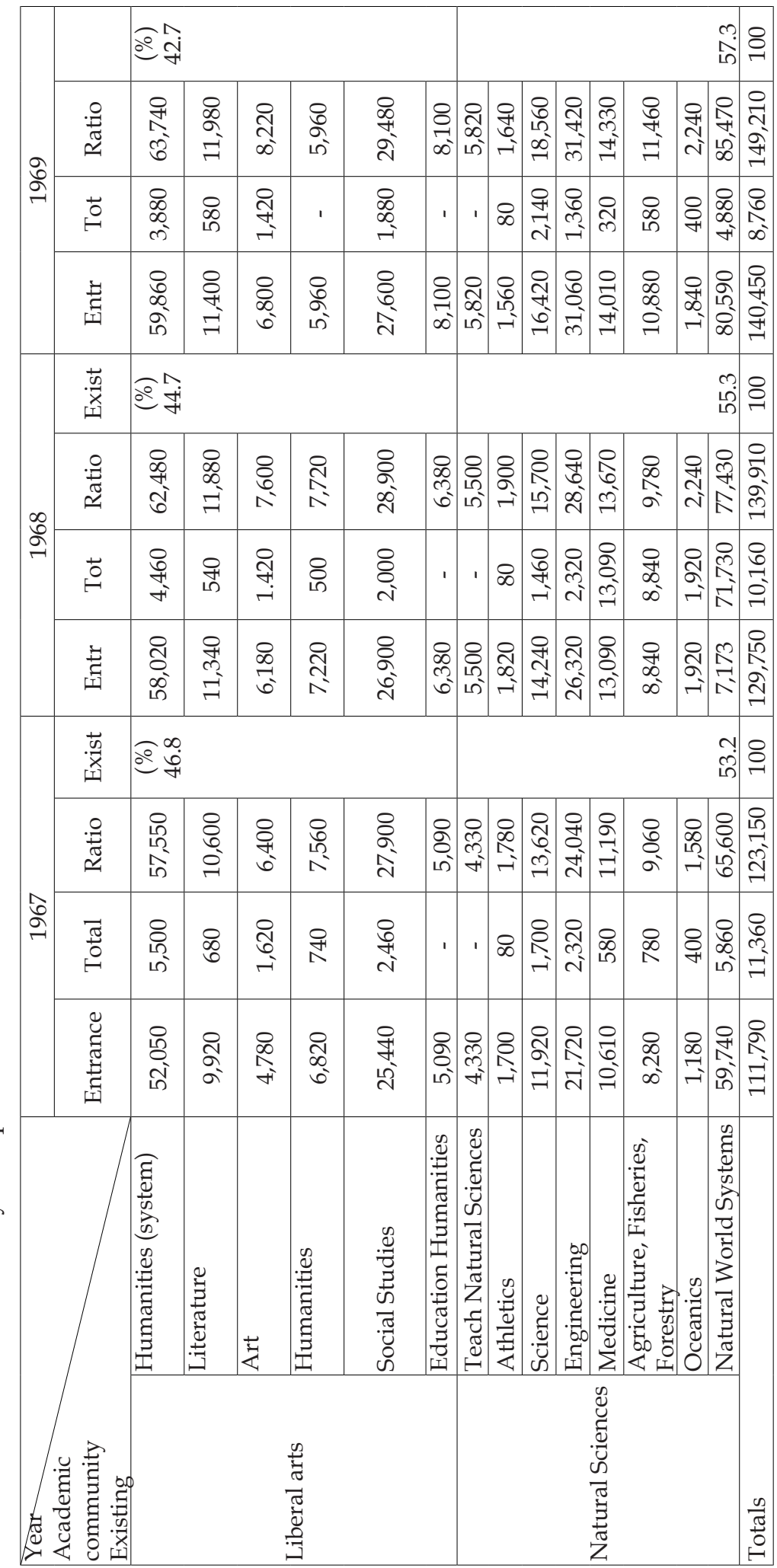

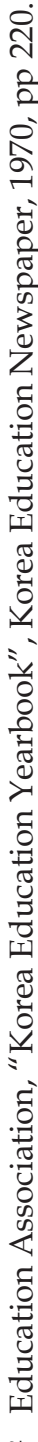


Table 10: Seoul National University Entrance Examination Subjects ${ }^{33}$

\begin{tabular}{|c|c|c|}
\hline \multirow[t]{2}{*}{ College } & \multicolumn{2}{|c|}{ Courses } \\
\hline & Mandatory & Elective \\
\hline Engineering & $\begin{array}{l}\text { Languages, mathematics, English, } \\
\text { Science (physics and chemistry) }\end{array}$ & General society, National affairs \\
\hline Agriculture & $\begin{array}{l}\text { The national language, mathematics } \\
\text { (Department of agriculture and } \\
\text { the Department of agriculture } \\
\text { boundaries and process only the } \\
\text { math), English, Science (choice } \\
\text { Physics Chemistry Biology. }\end{array}$ & $\begin{array}{l}\text { General public, affairs, animal } \\
\text { husbandry, afforestation, } \\
\text { sericulture, crops, agriculture }\end{array}$ \\
\hline Liberal Arts Letters & Korean, mathematics, English & $\begin{array}{l}\text { Physics, chemistry, biology, } \\
\text { geology, German, French, Chinese. }\end{array}$ \\
\hline School of Science & $\begin{array}{l}\text { Language, mathematics, II, English, } \\
\text { science }\end{array}$ & $\begin{array}{l}\text { National History, World History, } \\
\text { Geography, German, French }\end{array}$ \\
\hline Art & $\begin{array}{l}\text { Korean, English, General Social } \\
\text { practical skills. }\end{array}$ & \\
\hline Law & $\begin{array}{l}\text { Language, mathematics I, English, } \\
\text { General Social. }\end{array}$ & German, French \\
\hline Literature & $\begin{array}{l}\text { Language, mathematics I or II, } \\
\text { English. }\end{array}$ & $\begin{array}{l}\text { 1-Science (physics, chemistry, } \\
\text { biology, earth science); 2-general } \\
\text { social, national, and world history, } \\
\text { geography, French, German }\end{array}$ \\
\hline Teaching & Language, mathematics, I, English & $\begin{array}{l}1 \text { - science (physics, chemistry, } \\
\text { biology, earth science); } 2 \text { - } \\
\text { Literature }\end{array}$ \\
\hline Physical Education & $\begin{array}{l}\text { Language, mathematics, or } \\
\text { mathematics I II, English, physical } \\
\text { education theory }\end{array}$ & \\
\hline
\end{tabular}

Between 1973 and 1981, measures were taken to address the shortage of human resource which totaled 596,300 employees in the new economy. These included increasing the number of application to 5880 students into technical high schools, 1200 into technical colleges and 445 into university colleges specializing in engineering. Under the plan, ${ }^{34}$ technical high schools and 5 technical colleges became more specialized. Engineering education was enhanced by the introduction of specific and exclusive institutions majoring in engineering curriculum.

\section{Conclusion}

After 1969, South Korea moved from a predominantly agricultural economy to one that was based on exports and heavy industry with a focus on self-reliance and national security. This was achieved, in large part, by major investment and changes in

33 Chosun Ilbo, 6 September 1966.

34 Chosun Ilbo, 6 September 1966. 
educational policy. Those changes were far-reaching, widespread and fundamental. A new educational landscape was created with prominence given to Engineering, Science and Technology, underpinned by a spirit of cultural awareness and national pride. Such changes in economic policies contributed not only to enhancing Korean human resource but also transforming the country from a developing to a developed entity. 
